\title{
MEASURES TO INCREASE ECONOMIC THINKING OF YOUTH (Sample of the Republic of Uzbekistan economy)
}

\author{
Khasankhonova Nodira Isametdinovna
}

Tashkent Financial Institute, Senior Lecturer of the Department "Economic Theory" Republic of Uzbekistan

E-mail: xasanxonova@mail.ru

ORCID ID orcid.org/0000-0002-4283-2601

\section{Crossref}

http://dx.doi.org/10.26739/2433-202x

Issue DOI http://dx.doi.org/10.26739/2433-202x-2017-7-7

Article DOI http://dx.doi.org/10.26739/2433-202x-2017-7-7-1

Abstract: The article analyses measures to increase the economic thinking of the youth of Uzbekistan. The percentage of young people, their employment, adopted laws and directions in the political and economic activities of Uzbekistan are analysed. Also in article, describe the tools for ensuring the effectiveness of youth policy.

Keywords: youth, youth policy, credit, support of young families, economic thinking.

In conditions of dynamic development of the country and increasing competition in the global world, more attention is paid to youth. At the same time, the role of the state and society in this process, the intellectual development of young people and the attention paid for the full realization of her talent and abilities are always taken into account. Therefore, this issue is 
always reflected in all strategic directions aimed at ensuring long-term development of the state.

In the Republic of Uzbekistan on September 14, 2016, the law "On State Youth Policy" was adopted. The law provides for the provisions of the state youth policy, review the socio-economic, organizational and legal systems of measures realized by the state, and provide for the creation of conditions for the social formation and development of the intellectual, creative and other potential of youth. In the third article, the concept of young people is created out as a person between the ages of fourteen and thirty years old. Usually, work experience or entrepreneurship begins at the age of 18, in Uzbekistan at the end of 2016 from 18 to 30 years 7445.3 thousand ${ }^{1}$ people are youth (1 table).

1 - Table

\section{Dynamics of the younger generation compared to the population and employment (in thousands of people and in percentage terms) ${ }^{2}$}

At the end of the year

\begin{tabular}{|c|c|c|c|c|c|}
\hline Indicators & 2012 & 2013 & 2014 & 2015 & 2016 \\
\hline $\begin{array}{c}\text { The number } \\
\text { of permanent } \\
\text { residents } \\
\text { (thousand } \\
\text { people) }\end{array}$ & 29993,5 & 30492,8 & 31022,5 & 31575,3 & 32120,5 \\
\hline $\begin{array}{c}\text { Number of } \\
\text { young people } \\
\text { (thousand } \\
\text { people) }\end{array}$ & 7414,9 & 7522,3 & 7562,4 & 7542 & 7445,3 \\
\hline $\begin{array}{c}\text { Average } \\
\text { annual } \\
\text { number of } \\
\text { employed in }\end{array}$ & 12223,8 & 12523,3 & 12818,4 & 13058,3 & 13298,4 \\
\hline
\end{tabular}

${ }^{1}$ Accounted by the information of: Social development and living standards in Uzbekistan. T: 2017 year, P.37.

${ }^{2}$ Accounted by the information of: Social development and living standards in Uzbekistan. T: 2016 year, P. 14 and34, Social development and living standards in Uzbekistan. T: 2017 year, P.16 and 37.

Social science and humanities

N. Khasankhonova 


\begin{tabular}{|c|c|c|c|c|c|}
\hline $\begin{array}{c}\text { the economy } \\
\text { (thousands of } \\
\text { people) }\end{array}$ & 24,7 & 24,6 & 24,4 & 23,9 & 23,2 \\
\hline $\begin{array}{c}\text { Percentage of } \\
\text { youth from } \\
\text { the general } \\
\text { population } \\
\text { (in \%) }\end{array}$ & 60,6 & 60 & 59 & 57,7 & 56 \\
\hline $\begin{array}{c}\text { The } \\
\text { percentage of } \\
\text { young people } \\
\text { employed in } \\
\text { the economy } \\
\text { (in } \%)\end{array}$ & & & & & \\
\hline
\end{tabular}

From the table it can be concluded that between 18 and 29 years of age, at least an average of $24.1 \%$ of the population, it accounts for the bulk of an average of $58.6 \%$ of the employed population. Therefore, in the republic the main priority and task is to ensure a decent generation.

So, Uzbekistan having such potential, the main expectation does on as possible as can of employment of youth. President of the Republic of Uzbekistan Sh. Mirziyoyev noted on September 19, 2017 at the 72nd session of the UN General Assembly that: "Tomorrow's day, the well-being of the planet, depends on what kind of people our children will grow up. Our main task is to provide conditions for the self-realization of the youth, to create a barrier to the spread of the "virus" of the ideology of violence. We believe that for this we need to develop multilateral cooperation in the sphere of social support for the younger generation, protection of its rights and interests". From this point of view, the most actual issues for young people are creating decent conditions for finding their place in life, providing young people with all-round support, ensuring its professionalguidance and employment, and stimulating its initiatives.

President of the Republic of Uzbekistan Sh. Mirziyoyev, speaking on June 30 at the IV Kurultai of the public movement of youth "Kamolot", proposed to close the organization and on its basis to create the Union of Youth of Uzbekistan. The Union of Youth, which aims to ensure effective interaction with state bodies, non-governmental non-profit organizations and other institutions of civil society in the implementation of state youth policy, Social science and humanities

N. Khasankhonova 
carrying out professional activities under the motto "Youth is the builder of the future".

We can note the following areas that are aimed at multiplying and building the rational economic thinking of young people:

- Economic education;

- Loans for business development;

- Hypothec loans for young families.

As a part of society, the economic socialization of young people includes a spontaneous, relatively directed, socially controlled self-change of a person (youth). Socially controlled economic socialization is carried out within the framework of economic education, i.e. coincides in content with the notion of "economic education of students studying". This statement is especially important for the development of economic thinking. With the economic information, various economic phenomena and events, children and adolescents face daily: at home and in school, on the Internet, watching movies and TV programs, reading fiction, etc. Therefore, in modern Uzbekistan for economic education several resolutions were adopted. Among them, the most important is the Resolution "On Measures for the Further Development of the Higher Education System" No. PP-2909 of April 20, 2017. Each higher educational institution of the country Uzbekistan has close perspective partner relations with leading specialized foreign scientific and educational institutions, therefore on their basis there is a widespread adoption in educational process of the advanced pedagogical technologies, educational programs and the teaching materials based on the international educational standards as well as active involvement in scientific and pedagogical activities, conducting master classes, advanced training courses for highly qualified teachers and scientists from foreign educational partner institutions.

Also, it should be noted that the economic activities of young people are supported by the necessary amount of material resources. In this regard, the Development Fund of the Union of Youth of Uzbekistan will list $8 \%$ of the accrued amount of a single tax payment for small businesses. Subsidiary enterprises organized under the Youth Union of Uzbekistan for training in various subjects, including foreign languages, computer programming and business basics, will be exempt from all types of taxes for a period of 10 years. At the same time, $20 \%$ of the amount remaining at the disposal of the enterprise as a result of this benefit will be transferred to the Development Fund of the Youth Union of Uzbekistan. Every year in Uzbekistan about 
285,300 enterprises and organizations are created ${ }^{3}$, of which more than half are enterprises created by young people.

Taking advantage of the created conditions, the Union of Youth of Uzbekistan has already begun to form a young force that determines the future of the country. The Union began to study the interests and problems of the youth of Uzbekistan, who are abroad for the purpose of training or performing labor activities. The organization also takes measures to establish cooperation with international youth organizations and similar organizations of foreign countries, which will allow studying best practices in working with young people. To this end, the representatives of the Youth Union made visits to China in August of this year and to Kazakhstan in September. In the near future similar visits are planned to Russia, the Republic of Korea, Germany and other countries.

It should be emphasized that a number of concrete measures are being taken in the country, which are aimed at stimulating the activity of youth in social and political life. The main step was the launch of the Youth Press Club, which became a platform for high-quality and timely coverage of life events of young people. An open dialogue will be held between the representatives of state bodies, the expert community and the mass-media for a constructive discussion of youth issues. This platform will also serve to increase the activity of young people in the socio-political life of the country.

Also, loans are provided to young families in the country in accordance with the requirements of the Presidential Decree No. UP-3878 of May 18, 2007, "On Additional Measures for Material and Moral Support for Young Families" and "Regulations on the procedure for the issuance by commercial banks of loans on a preferential basis to young families", registered by the Ministry of Justice of the Republic of Uzbekistan for No. 1697 of July 18, 2007. They are about 3,000 proportions the minimum wage and are issued for a period of not less than 15 years.

In the development of market relations, the most important task is to develop the economic thinking of young people. To this end, we believe that we must work out directions for improving the economic thinking of young people. So, we give the following suggestions for improving economic thinking:

- Continuity of self-development in any sphere of the industry;

-Integration cooperation between science, education and industry; 
-Youth is a very flexible economic resource; therefore, scientific and technological progress is important for sustainable economic development and ensuring a decent standard of living for the people of our countries;

-Give more benefits to young people when creating small businesses and entrepreneurship.

These proposals will ensure sustainable growth not only in economic thinking, but will also ensure the future of Uzbekistan's socioeconomic policy. Our state has chosen the continuous self-development of young people from the point of economical thinking, because the human potential (youth) is promising and flexible in relation to human resources for an effective state policy.

\section{References:}

1. The Law of the Republic of Uzbekistan "On State Youth Policy" No. ZRU - 406, September 14, 2016.

2. Decree of the President of the Republic of Uzbekistan "On additional measures for material and moral support of young families" from No. UP3878 dated May 18, 2007.

3. "Regulations on the procedure for the issuance by commercial banks of loans on a preferential basis to young families", registered by the Ministry of Justice of the Republic of Uzbekistan for No. 1697 of July 18, 2007.

4. Decree of the President of the Republic of Uzbekistan "On measures for the further development of higher education" No. PP-2909 of April 20, 2017.

5. Social development and living standards in Uzbekistan. T: 2016 year.

6. Social development and living standards in Uzbekistan. T: 2017 year.

7. Uzbekistan in figures 2017. T.: 2017 year.

8. Lex.uz (Uzbek law portal) 